\title{
LECTURA HERMENÉUTICA DE DOS AUTORES LUIS CERNUDA Y CÉSAR DÁVILA
}

\author{
Rosario A'Lmea Suárez*
}

En la Poesía, el poder de la creación es mayor que cualquier lógica; por lo tanto, la construcción verbal no es racional ni recta ni gramatical; puede ser relacionada con el no-pensamiento, el anti-discurso, la no-comunicación. Esta aparente violación de lo mimético, de lo canónico, es el logro de una tensión conceptual que refracta una confusión de deseos, frustraciones, imágenes de la conciencia: pone en libertad el súper-yo ético o el ser frente al parecer.

En este plano, la lectura también cambia y debe sondear las huellas de lo no visible e increpar las vacilaciones, repeticiones, rupturas, desvíos, metáforas para sentir las implicaturas del juego que requiere de un lector/a-poeta, pues se exige un acercamiento sensible, puesto que:

El poema sólo existe en sentido de su reacción y su oposición dentro del sistema de la lengua, su valor comunicativo de-

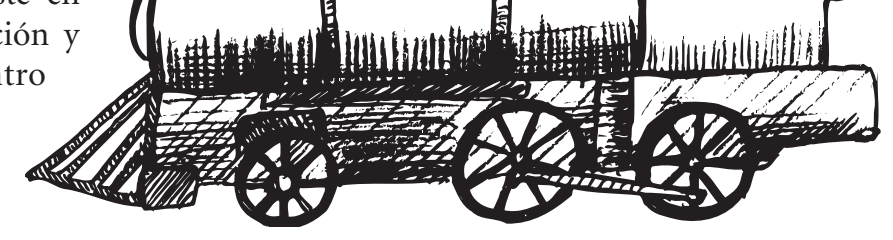

ja de tener relevancia (inoperante), porque es una expresión del pensamiento inagotable y autoconsciente, destructor de la sustancia objetiva a la cual transforma, a través de la sustracción y la diseminación. 
En la sustracción, el poema es una máquina de negatividad que somete al objeto a la prueba de su misma ausencia. En la diseminación, entre tanto, el objeto pierde su valor no por una falta, sino por un exceso que lo disuelve y distribuye, anagramáticamente, de forma plural y recurrente ${ }^{1}$.

La presente lectura toma a dos creadores líricos que iniciaron un proceso de búsqueda de la Poesía. El lenguaje poético ha sido la labor de toda su vida y por el cual han sufrido cambios, a su vez, los han suscitado en las letras de sus respectivos países; lo que les ha dado un sitial en la historia de la Literatura.

Se ha tomado a Luis Cernuda y César Dávila, porque son dos voces, cuyos trabajos reflejan una poesía de búsqueda dolorosa, agresiva y sublime.

La búsqueda de la Creación en ambas conciencias es un reto que genera particulares semiosis y es un leitmotiv.

En Cernuda la partida se da a través de la mirada; crea otra realidad que le produce sosiego. Pero, algunos recuerdos se convierten en tormentos que atacan su conciencia para mantener al yo poético en un eterno sufrimiento. Dávila, en cambio, em- prende la partida a través del canto, pero ese errar no es tranquilo ni de expectación, es de lucha, de dominación; la voz poética es agresiva al poseer; toma la procreación como metáfora de su actuar; sucumbe al final cuando la considera como infructuosa, pues sólo ha conseguido la nada.

En sí, el camino emprendido por cada uno es único y, a la vez, parecido. En este proceso, el valor del exilio, abandono, alejamiento, éxodo o huida es primordial, porque es la erranza propia del poeta.

\section{Luis Cernuda: el exilio, camino de encuentro con su tierra prometida}

Cernuda (Sevilla 1902, México 1963) despliega, bajo la experiencia del exilio, una carga emotiva en su estética. El lenguaje en todos sus niveles -fonético, morfosintáctico, semántico- es el camino de encuentro con su mundo de deseos edificado con restos de la realidad vivida, a través del cual construye "su" Tierra Prometida: la creación poética.

La consolidación de esta conciencia lírica plasma en esta Tierra Prometida todo el bagaje personal,

1 Raúl Antelo, Poesía Hermética y Surrealismo, http://www.geocities.com/a fonte 2000/antelo4.htm, consultado el 04-05-06. 
por ello es menester sentirla como una focalización del enunciado; teóricamente se parte de la propuesta bajtiniana de la Enunciación, que plantea en una de sus aseveraciones la creación lingüística como una conjunción con una realidad, donde se refracta una determinada manera de mirar el mundo. El corpus empleado: algunos textos de Las nubes, con relevancia en el poema "Cementerio en la ciudad"2.

\section{CEMENTERIO EN LA CIUDAD 3}

Tras de la reja abierta entre los muros, la tierra negra sin árboles ni hierba, con bancos de madera donde allá a la tarde se sientan silenciosos unos viejos.

En torno están las casas, cerca hay tiendas, calles por las que juegan niños, y los trenes pasan al lado de las tumbas. Es un barrio pobre.

Como remiendos de las fachadas grises, cuelgan en las ventanas trapos húmedos de lluvia. borradas están las inscripciones de las losas con muertos de dos siglos, sin amigos que les olviden, muertos clandestinos. Mas cuando el sol despierta, porque el sol brilla algunos días hacia junio, 5 en lo hondo algo deben sentir los huesos viejos.

Ni una hoja ni un pájaro. La piedra nada más. La tierra.

¿es el infierno así? Hay dolor sin olvido, con ruido y miseria, frío largo y sin esperanza.

Aquí no existe el sueño silencioso 
Cuando la sombra cae desde el cielo nublado y el humo de las fábricas se aquieta en polvo gris, vienen de la taberna voces, y luego un tren que pasa agita largos ecos como bronce iracundo. No es el juicio aún, muertos anónimos. Sosegaos, dormid; dormid si es que podéis. Acaso Dios también se olvida de vosotros.

Cernuda se aleja de la realidad y el exilio es el único camino para descubrir la Creación Poética

El poemario Las Nubes compendia creaciones de una experiencia vivencial, que demuestra la madurez de una voz y consolida la visión cernudiana del mundo. La búsqueda aparece en las primeras producciones que hablan de una poesía pura, entre tradicional y de vanguardia, entre romántica y realista. El encuentro tan anhelado no se sabe

Es necesario emprender un éxodo hacia la consecución de los deseos.

Ese exiliarse de la humanidad, lo librará de la falsedad. cuándo ni dónde -ni mucho menoscon qué ocurrirá. Sólo se espera su ruptura y liberación de lo común.

El desaire de sus coterráneos, la guerra, el éxodo a tierras diversas, el despego de lo religioso por lo pagano crean un divorcio con la realidad "civilizada". Se parte de ésta para iniciar una errada al mundo interior, con la certeza de encontrar su Tierra Prometida. No la venidera luego del Juicio Final. La buscada por el autor es otra. Se la puede llamar propia y más real que cualquiera geográficamente localizada. Esta resignificación es un rechazo a la existencia de una sola y única verdad.

El sentir del terruño agredido por la guerra, los amigos que olvidan, destruyen la percepción de la España real como el "hogar". Es necesario emprender un éxodo hacia la consecución de los deseos. Ese exiliarse de la humanidad lo librará de la falsedad.

La marcha hacia la libertad: la suya lo guía. Hay que aclarar que el lema "libertad" no es el de la pobre 
concepción humana. Se lo significa como el anhelo valioso y existencial, vislumbrado sólo por los poetas. Pero, el precio de comprender aquello implica el alejamiento del tiempo y espacio humanos. Sin embargo, el poder obtenido hace de la mirada su código y el alma encuentra su expresión. Aquella ida le prohíbe ver atrás, le obliga a seguir el camino abierto por el destierro. No importa lo tortuoso que sea; lo peor es quedarse en una ciudad borrada y sin amor. Aquella que es menos que un cementerio.

Es así que todas las edificaciones humanas se convierten en la consolidación de la mentira de la civilización: hipocresía de piedra que le insulta y lo lleva a divisar otros senderos: los que están dentro de sí mismo. Ahí descubre que lo ansiado: sus deseos más recónditos se hacen carne-tierra, se hacen palabra, se hacen poesía. Palpita un universo no descubierto, pero latente que necesita del éxodo para construirse.

La creación es lo que tanto ha buscado. La lejanía, la soledad, la noche, son momentos (motivos) que le mostraban ráfagas de su Tierra Prometida. Pero la voz poética enceguecida por la no-realidad (mundo concreto para todos), no la alcanzaba a vislumbrar. Su terruño no estaba ni en España ni en otro país. Para delei- te suyo, está en sus manos, en su voz, en su imaginación, en sí mismo. Es el poder que tiene el poeta cuando toma la palabra para hablar; lo que silencia el viento y las voces humanas; éstas espantadas reniegan de la Creación (poesía), se encierran en su esclavitud de almas civilizadas, vacías de amor; se refugian en sus fábricas, bares, trenes, calles, muros,...

$\mathrm{Su}$ reacción es de rechazo, primero hacia lo que se constituye como hogar físico, las casas, la ciudad. Para él, ésta es un cementerio, de donde debe alejarse rápidamente. Sólo así conocerá la verdadera libertad, $s u$ tierra, por ser su creación. Todo este sentir apocalíptico lo vierte en el poema Cementerio en la Ciudad.

En una escala semántica decreciente se inicia con un título, donde se presentan dos conceptos negados: No-vida / No-muerte; bajo una simple lectura denotativa, esta frase es una localización, pero hay que connotar el juego de antítesis. Cementerio es un espacio de muerte, mientras que la ciudad es uno de vida. En el transcurso del enunciado se da una sincronía hasta que deviene la transmutación.

La idea de que la ciudad es un cementerio, de donde se debe huir se perfila dentro de un escenario sonoro pesado. Los silencios que se emplean al final de cada uno de los gru- 
pos fónicos hacen resaltar más aún las cúspides tonales entre las cadencias, ubicadas en versos largos, preferentemente endecasílabos -herencia del Siglo de Oro- y alejandrinos mixtos, que no son sino la síntesis de dos heptasílabos con acento en segunda y sexta; se alternan también los polifónicos, lo que enfatiza su vena modernista; su libertad espiritual se denota, incluso, en la combinación de pentadecasílabos, hexadecasílabos y heptadecasílabos -regidos con los acentos de los simples-; lo que le brinda una solemnidad que asciende a lo elegíaco. Esta melodía se siente claramente en las cadencias y en las semi-anticadencias presentes y distribuidas con carácter sensorial de distanciamiento casi parco dado al poema. No es raro, porque es el alejamiento de lo que fue una vez la vida real de Cernuda-hombre: su país: hoy, muerto. Es el poeta refractado en la voz poética escuchada.

Este halo lúgubre se acentúa con el empleo de complementos circunstanciales, ausencias verbales -la acción, la pasión- y el predominio de sustantivos: característicos del tono descriptivo, por excelencia espacial. Se reitera la quietud, la lentitud, lo oscuro, lo olvidado. Es así como con- vergen en un solo sentido lo morfosintáctico y lo fonético. Por eso, Cernuda es el gran poeta de su tiempo, así lo aseveró Federico García Lorca.

Esa lejanía, quietud y descripción comparten lugares reales y evocados en el plano de la memoria, para ello, el ingenio del poeta nos hace jugar con la focalización: recurso imperceptible, pero esencial si se conectan dos puntos, los ojos del lector y los ojos de la voz poética en un descubrimiento unísono, que une dos almas intercambiando un lenguaje propio.

El valor dado a lo visto, es un descubrimiento suyo único, ocurrido, según sus propias palabras, en...

Una de esas tardes, (...), [cuando] las cosas me aparecieron como si las viera por vez primera, como si por primera vez entrara yo en comunicación con ellas, y esa visión inusitada, al mismo tiempo, provocaba en mi la urgencia expresiva, la urgencia de decir dicha experiencia... ${ }^{4}$

El viaje visual, a través de su mirada va de planos generales a primeros planos; cuando la tensión predomina se presentan los primerísimos primeros planos para volver abruptamente a la presentación de los contextos. Es- 
te ir y venir sólo se puede hacer en el espacio del nostos, de la reflexión.

A más de ser espacial -mirada-, la focalización se presenta en el uso de la intensidad expresiva -tensión semántica, por rupturas conceptuales: electrocución (tacto) física y psíquica- se hace evidente en aquellas estrofas de ocho líneas versales -recuerda a su preferido, Bécquer, con la octava italiana-, mientras que las de siete preparan la crisis y el estrépito de la conclusión. Así, por ejemplo, en el verso $12,21,22$ y 30 -este número múltiplo de tres "coincide" con el Sujeto Superior-Creador increpado-, sin amigos que les olviden; ies el infierno así?... . ... ... la vida/ se agita entre estas tumbas, como una prostitutal prosigue su negocio bajo la noche inmóvil; acaso Dios también se olvida de vosotros.

Para traslucir mejor este juego visual de planos, detengámonos en la primera estrofa; los ojos de la voz poética están lejos: es en picada que muestra la totalidad: Tras de la reja abierta entre los muros, / la tierra negra sin árboles ni hierba, con panorámica: con bancos de madera.../...están las casas, ... hay tiendas / calles..., y los trenes. En estos versos tampoco pueden faltar los encabalgamientos, característicos del autor, conductores de la libertad del pensamiento a otras sensaciones, más intensas, más reflexivas.
Los encabalgamientos son notas musicales que se alargan hasta el infinito para que sea más doloroso el regreso al silencio buscado ansiosamente, por el corazón, por la respiración. Son visitas fugaces del lector a la muerte. Es el reconocimiento de la vida en el aliento de la agonía. Esta musicalidad se da esencialmente por el ritmo, más que por la rima, que no es pródiga sino escasa, aunque entre el verso dos y cinco hay una rima asonante (-ie...a), que es más un fenómeno semántico que acústico, -nótese que esta combinación fonética se repite en otras líneas del mismo poema, lo que, de manera global, sí es una recurrencia rítmica de totalidad; es la música de un llanto de trasfondo que grita: "no"-, pues separa dos mundos, el del movimiento y el de la quietud. Sin embargo, ambos, circundados, encerrados, entre muros, sin vida. Es el cuadro de la ciudad como un cementerio. ¡La ciudad hay que dejarla, huir, exiliarse; buscar la creación como refugio, como Tierra Prometida propia! Es un grito de infantilismo y soberanía si tomamos unos conceptos de Maurice Blanchot, tan bien explicados a partir de la estética de Frank Kafka.

El primer quiebre y tensión se da con el cierre de esta estrofa, que es una aseveración: un juicio, "Es un barrio pobre". Con ella, un propicio 
cuestionamiento asoma: qué clase de "pobreza" puede tener ese "barrio". Es la existencial, pues la respuesta está en las primeras líneas. Regresemos a los lemas que indican la no-libertad: "muros, reja, en torno". Todos ellos tienen la connotación de prisión, recalcada por la vacuidad: "tierra negra” - por relación simbólica, el color indica que está llena de humos, no es estéril, entonces aquí estamos frente a un juego de antítesis, indicador de que lo que tiene vida pierde en esa realidad- "sin árboles ni hierba, /.../...... silenciosos". Es una negación de la esencia.

El ojo de la voz poética cambia de actitud, de un alejamiento e impersonalidad evidentes, salta a los detalles. Es una posesión de lo descrito, como lo haría el dueño, el creador, el dador de la memoria. Por ello se puede reconocer la "ventana" como libertad; la "lluvia" como purificación, porque en su cosmovisión, el agua tiene esa virtud en especial, el "mar". Similar simbología aparece en los textos de García Lorca, en especial, en Yerma, lo que nos lleva a reconocerlos como de la misma generación. Sin embargo, lo lúgubre sigue, porque esa es la ambientación que se siente en el alma. Esta vez se percibe en "las fachadas grises", se siente en "las losas de los muertos de dos siglos". La ventana, antes libertad, ahora es una entrada a la muerte, pues las losas tienen su forma. ¿Será que la muerte en este caso podría ser entendida como una forma de libertad? ¿Pero en qué dimensión? En la real, en la del mundo creado. Mas, la decadencia se evidencia en la resonancia de palabras como "viejo, remiendos, trapos".

La verdad viene cuando se descubre que las casas son las tumbas -antes se las menciona, pero como parte del cementerio, ahora son la metaforización de la ciudad-, donde no se lee ni siquiera las inscripciones, porque el tiempo y el olvido han hecho su apogeo. El olvido es el sentimiento característico de los humanos; sufrido tanto por la voz poética y del que no puede huir, incluso en su Tierra Prometida; es así, porque son herencias de la realidad que lleva en su alma, en su cosmovisión del mundo.

La definición dada a los seres humanos es drástica, no son más que "muertos clandestinos". Sólo se reconocen, cuando el "humo de las fábricas -el progreso, la civilización- se aquieta". Ese será el momento, cuando se escuchen sus propias "voces", dejen entonces su cueva árida de "hoja" y de "pájaro". Cernuda ya ha dejado ese mundo, está en el proceso de creación su aliciente; ha encontrado su Tierra Prometida, la que necesita 
para vivir y que el resto de la humanidad viva en su cárcel es su problema (infra se analizará la percepción de poeta al respecto). Él ya les ha advertido; por ello lo han repudiado y marginado al olvido.

Este último corresponde al segundo momento de tensión; aun, es la única vez cuando la voz poética deja de ser impávida y se filtra un resentimiento vivido, que ha atormentado su corazón de poeta; incluso en su placentero instante de eterna creación "hay dolor sin olvido". Es el dolor por la amistad perdida. Él sufrió el olvido de sus amigos y eso se lo devela en el verso doce del poema: "Sin amigos que les olviden". Ese "infierno", que es el verse no reconocido por sus iguales, marcó mucho de su expresión; pero en este verso es más cruel su percepción, pues los amigos son sólo para olvidar: esa es su esencia. $¿$ Herencia de algún demiurgo? Esta pregunta se responde en el verso treinta: "Acaso Dios también se olvida de vosotros". ¡Pavoroso este concepto sobre la humanidad y de Dios! Pero muy cierto en el tiempo-espacio vivido.

\section{La Tierra Prometida, la que todos esperan, no existe}

La ciudad hija de la humanidad ha heredado la esencia de la prisión, de "piedra nada más"; de ella se debe salir para encontrar el camino de la Tierra Prometida; aquella que no tiene límites ni espacio, porque es la misma creación poética y "porque, ahí, el sol brilla algunos días hacia junio". Por ello, hay que exiliarse, huir. La voz poética sabe que el ser humano es un exiliado por naturaleza y por propia decisión, pues no desea ver- escuchar las verdades existentes, sino que se fía de una sola y en ella se empareda. Pero, Cernuda se exilia de la humanidad. Y esta acción le hace ser repudiado por sus iguales. Es el rechazo que sufre quien es diferente, quien es vidente, quien es poeta. Esta aseveración es defendida también por Dávila en muchos poemas como se lo ejemplificará.

La reflexión sobre el exilio es existencial, pues, si la voz poética ha sido exiliada por ser poeta, todos los seres humanos también lo son porque viven olvidados, solos, abandonados de la mirada de los otros y del Otro.

$\mathrm{Al}$ abandonar la dolencia humana, esta conciencia no sufre un doble olvido, sino uno solo. Tan doloroso que lo hace quedarse en sí mismo, en su Creación. Este reconocimiento presenta el tercer momento de tensión, porque se descubre que la tierra prometida de la tradición bíblica es una falacia, porque es el encierro en las leyes, en las paredes, en las fachadas, en las tumbas, donde “... no exis- 
te el sueño silencioso / de la muerte, que todavía la vida se agita entre estas tumbas, como una prostituta prosigue su negocio bajo la noche inmóvil" -la eternidad-.

\section{Los seres humanos refractan esta esencia terrible en su construcciones, las ciudades, que son cementerios y en las acciones con sus hermanos -al olvidar-.}

En este plano, la vida es una mercancía que se vende al mejor postor, es en sí un cuestionamiento sobre la existencia -acto de rebeldía y de herejía-, pues ese regalo es más bien una condena, una manipulación del cuerpo: los seres humanos refractan esta esencia terrible en sus construcciones, las ciudades, que son cementerios y en las acciones con sus hermanos -al olvidar-. Dávila la refleja en sí mismo, a tal punto que su presencia le obliga a destruirla desde sus simientes, porque vislumbra su vacuidad.
Esta increpación al Ser Supremo sobre su acto de mal "padre", se reitera en muchos de sus poemas. En $\mathrm{Ce}$ menterio en la ciudad, verso treinta, aquella llega a ser sarcástica y doliente, puesto que se imbrica con el sufrimiento del olvido, que ha hecho carne en su conciencia. Además, esa carga emotiva se constata en la preferencia por el verso de arte mayor, con una inconstancia en cada línea versal, sin rima estrófica, pero con gran riqueza rítmica interior, propia de la cadena hablada.

Hay que notar que en este verso no se emplea la suspensión, pues se sabe lo que se dice y se lo hace con desparpajo -aunque blasfeme- ya que, es el dolor que habla. Es tal el poder del olvido que llega hasta Dios. La voz poética no se incluye, porque vuelve al recurso del alejamiento, de la reflexión, que es muy existencial. Ya se ha exiliado de ser un Ser Humano por completo. Está en su mundo de creación poética.

Este repudio por la existencia de una sola verdad hace que odie al "padre”, su ley, la sociedad, lo hegenómico. Los otros seres humanos lo catalogan como "extraño". Por ello nadie lo considera un igual, sino a quien deben alejar. Sólo el canto hace del extraño un soñador. Lo aproxima a lo eterno: el crear. Esta conexión con este lema, lo seguirá tam- 
bién Dávila, que cambiará los medios o estadios escogidos, la actitud violenta con que enfrenta la creación, la lucha con su mundo, la impotencia y la desesperanza de su acción que lo sume en la nada.

En el mundo dejado, las vidas humanas se llenan de odios, de frustraciones, de envidias, a tal punto que

La muerte se diría Más viva que la vida 5 .

A través de esta paradoja indica la decadencia de lo humano -esta sensación en la voz daviliana lo hace destructivo de todo, de sí-, por eso, la conclusión que saca la voz poética de la realidad es dolorosa y escribe estos versos:

La realidad más honda de este mundo:

El odio, el triste odio de los hombres ${ }^{6}$,

Asimismo, ese repudio por su condición de poeta, lo hace sufrir. En este caso reflexiona sobre lo doloroso de vivir como creador -demiurgo-, puesto que recibe sólo el odio de la humanidad. En estas líneas se siente la tristeza y, a su vez, la rebeldía que le prodiga su calidad de cantor:

Triste sino nacer

Con algún don ilustre

Aquí, donde los hombres

En su miseria sólo saben

El insulto, la mofa, el recelo profundo Ante aquel que ilumina las palabras opacas Por el oculto fuego originario ${ }^{7}$.

Dentro de esta cosmovisión, se resignifica el lema "muerte" -siguiente punto de tensión- deja de denotar el fin de todo y adquiere una implicatura de lugar anhelado, de consuelo, un sueño silencio, hermano del de la creación. Este sitio es descubierto sólo después del arribo a su antesala, la soledad; allí habitará el poeta como preludio de su erranza por el camino de la literatura.

Qué concibe al poeta cual lengua de su gloria $Y$ luego le consuela a través de la muerte8.

Esa antesala, en un inicio, es impuesta indirectamente por la misma voz poética -por la acción de buscar su Tierra Prometida- y luego es la respuesta cruda y hosca de sus congéneres; mas eso sólo pasa a quienes

\footnotetext{
"Un poeta muerto", v. 34-36, p. 67.

"Noche de Luna", v. 61-62, p. 63.

íd., v. 16-22.

"A un poeta muerto", v. 97-98, p. 68.
} 
descubren el don de ser demiurgos. Aquel triste reconocimiento de su esencia es un acto de felicidad y júbilo; por ello se conforma con el exilio y elige la palabra como bandera. Sabe que tiene que vivir asechado, repudiado, vituperado, aunque libere fragmentos de mundo que llenan de vida la vida-muerta.

Por eso se justifica su reticencia con la muerte, el olvido, el encerramiento, el silencio, la esterilidad, la quietud, el abandono, porque es la única herencia humana que ha recibido, la cual le obliga a llevar a cuestas su mundo de Creación. Esa poquedad humana -las ciudades, las tumbas- se contrapone con la riqueza de la naturaleza (de las otras entidades no procesadas por el hombre) que se abre ante sus ojos y lo sume en otra visión. Es el valor de lo descriptivo y de la focalización: forma de mostrar, como se lo ejemplificó en el poema objeto de la interpretación.

Si volvemos a leer el fragmento de Historial de un libro, se nota el valor que da a la mirada, a la experiencia no es más que la concienciación de su soledad, de la necesidad de emigrar e ir en busca de...
Este camino es la historia de su verdadera presencia en la tierra. Para ello recurre a la lengua, que está entre Dios, la tierra y él. Como nadie la puede poseer completa, es necesario crear un nuevo mundo: $s u$ Tierra Prometida, que en sí, es la constante creación poética. Todo lo humano -el pueblo, la ciudad-se desvanece. Su rumbo es otro: "las nubes, los deseos, las quimeras". La existencia no está "entre un pueblo hosco y duro", donde "el odio y destrucción perduran siempre/ sordamente en la entraña / toda hiel sempiterna del español terrible,"10.

El peregrinar de $s u$ existencia -no vida, pues esa es la humana- sin un espacio propio, lo hizo vivir esa notierra. La invasión de su patria por la guerra, la transformó en no-patria, en consecuencia, la repudia en ese presente y la rememora con lo que logró rescatar del mundo dejado en la memoria. Su actitud es dura ante esa no-patria, que crea la imagen de otra voz, que lejana e impersonal dice: “...España ha muerto”"1.

El hecho de crear otra patria dentro de la palabra y desde la poesía es la labor de un poeta, que toma lo heredado para darle otro valor: donde

9 "A un poeta muerto", v. 3, p. 67.

10 íd., v. 11-13.

11 "Impresión de destierro", v. 44. p. 110 
lo muerto es generador de vida. Su exilio -abandono por parte de sus congéneres y huida de sí a ellos por su rechazo y olvido- es un detonante, que genera el otro mundo, el del Arte, llamado Tierra Prometida. No se da por una alianza, ni una recompensa, sino por el deseo de ser, de buscar la esencia del ser humano; aquella perdida en la religión, en la cultura, en la guerra, en las bajezas, que transforma todo en artificial; olvidando el punto de encuentro entre pasado y futuro, entre tradición y modernidad, entre instante y eternidad. El lugar concebido, su Creación, es un lugar donde los opuestos coexisten para generar y no para destruir; es la validez del amor como salvación de los Seres Humanos. La ley y la obediencia son hacia la esencia del género.

El considerar el exilio como necesario para crear la Tierra Prometida es lo que constituye la vida humana y artística de la voz poética de Cernuda.

Sin esta interpretación, el exilio y la realidad misma se convertirían en un "infierno", donde sólo habría "muertos anónimos o clandestinos", esperando el "juicio" para los "huesos viejos".

En sí, Cementerio en la Ciudad es un poema de un matiz lúgubre, pesado y rebelde. Tiene la desazón de aquel ser que descubre que la reali- dad mirada por sus ojos, no es la que desea.

Lo lúgubre, como se ha ejemplificado, se da en la ubicación geográfica y en la magistral utilización de la focalización. El uso cromático del fondo gris completan el marco del encierro; aquel propio de las ciudades, de los cementerios, cuyos muros, casas circundantes sólo quitan el poder de la mirada: pequeñas ráfagas de la LIBERTAD DE LA EXISTENCIA se presentan cuando se mira "la reja abierta, la ventana o las calles por las que juegan niños".

La pesadez se nota en lo morfosintáctico, fonético, semántico, que preludian la quietud de los muertos en vida, indispensable para la reflexión.

Asimismo, es rebelde pues insulta las edificaciones humanas, la civilización que trasmuta la naturaleza y la asfixia en silencio. Por eso, la vida se convierte en la aniquiladora en acción: "una prostituta [que] prosigue su negocio...” El poema $-y$ toda la poética cernudiana- es el grito de reflexión sobre lo que es la vida humana, sus construcciones y creencias, frente a las razones de la EXISTENCIA. Es contrarrestar la validez de las leyes humanas y las leyes naturales, enunciado también en la condena de Antígona. Esta preocupación es la que todo poeta lleva de manera intrínseca, sin importar la nacionalidad. En el 
Ecuador, por ejemplo, este sentir desgarrador se lo encuentra en algunas voces como la de César Dávila.

\section{El sentimiento de exilio y bús- queda de la creación en un poeta ecuatoriano}

La presente lectura toma el libro de César Dávila Andrade (Cuenca 1918 - Caracas 1967). En un lugar no identificado, el cual se lo ha catalogado como poesía hermética debido al uso semántico del mismo. Pero, más que eso, el poeta ecuatoriano es una conciencia creadora, una voz poética increpadora y muchas veces interpretada como irreverente. Sin embargo, hay que ir más profundo en el análisis para dilucidar cómo la creación poética -la tierra Prometida de Cernuda- se convierte en algo inalcanzable, pero que debe ser poseído. Lo trascendente es el proceso que lleva a aquella consecución, es decir, la acción de búsqueda. En cada autor, este encuentro es sentido como un enunciado distinto. Ya se vio en Cernuda, ahora hay que escuchar a Dávila.

La voz poética demuestra la preocupación por la creación como un trayecto que debe iniciar. Para ello, se aleja, se exilia. En este caso particular, la bebida se convierte en un aliciente que lo lleva a lo anhelado. Si en la cosmovisión de Cernuda, la mi- rada tenía un valor catalizador, en Dávila, lo es el cantar. Su trayecto se vuelve doloroso. Esa sensación lo transforma en una voz iracunda que se muestra agresiva y tajante, la utilización sintagmática así le sirve de refracción, porque la mayoría de sus construcciones encierran pequeños universos constituidos e infranqueables. Tan cerrados que crean su propia significación, dándoles independencia del resto de líneas versales, lo que produce una gramática propia. La labor del crítico es dilucidarla.

En otro punto, hay que denotar la desesperanza, a pesar de que Cernuda y Dávila tienen en sí el ansia de la Creación como un cronotopo, los momentos de tensión difieren así como sus detonantes; asimismo, la desesperanza de cada voz poética es distinta, en el primero, el alejarse y descubrir que la muerte es la vida da a su percepción del mundo otro rumbo; en contraposición con el desasosiego, la desesperanza y el pesimismo de la voz cernudiana que vislumbra la nada, en sí mismo.

A lo largo de su producción este actuar es una constante. Se imbrica con lemas distintos que refractan los caminos seguidos, encontrados o permitidos para la finitud humana.

En cuanto a su reflexión sobre el lema "creación" se intercala con varias utilizaciones sémicas, converti- 
dos en lugares de tensión a lo largo del texto ejemplificado y continúa en el resto de su obra. Su culminación se constata en los últimos poemarios, donde el lenguaje poético es rotundamente hermético. La lectura exigida no es lineal, sino de catálisis.

Primeramente, se parte de la procreación humana como primer momento tensionante. El "sexo" es un acto metaforizado, donde todos sucumben, incluso el "Jefe de Arquitectos"12, que se lee como el Sumo Creador. Sin embargo, esta sincronía de energías es vista como una transmutación. La percepción compartida por el lexema toma dos implicaturas:

- el acto como tal, corpóreo y mundano que los confunde y distrae;

- el acto que llega a algunos, a esferas del placer como conjunción -comunicación-, denominada Creación: diálogo de significados.

Estas dos visiones se confunden en toda la poesía como una, pues, en esta lucha de opuestos, se desea denotar la diferencia: "En la materia termina el entusiasmo del altísimo"13.
La (pro)creación humana, en "Origen II", muestra a los padres de la voz poética cumpliendo un acto aberrante. Mas, cuando esta acción deviene en el logro poético, pone al ejecutor en un parangón divino, aunque parta del primer estadio.

Me tentaré lejos de Dios, mano a mano a mí mismo, con la sinceridad hambrienta del perro que duerme temblando

sobre el pan enterrado por su madre ${ }^{14}$.

Cuando la voz poética se deja escuchar, se descubre en una suerte de confesión, que trasluce su anhelo, su búsqueda.

Entré y salí en busca de nuevas especies de sufrimiento en la embriaguez de las escaleras de caracol porque ya había resuelto encontrar el asco y la sabiduría en mi mismo, a la luz de la espina emplumada15.

Esta búsqueda, antes de descubrir el valor del exilio, destruye lo creado por otro -a igual fin someterá su labor-; así es como el valor de su Creación tendrá legitimidad. Por ello re-
13 íd., p. 301.

14 íd., p. 321.

15 íd., p. 325. 
calca: "Mis manos zumban entre las termitas / y destruyen la rosa invisible / ..."16 Además, sabe que ese éxodo es hacia sí, lo que le hace aceptar su calidad de solitario. Es decir, el Ser Poeta. Es tal su responsabilidad que grita en un poemario anterior a En un lugar no identificado:

" ¡Ah del poeta que hiere con su citara almejilla del pobre

y canta los lunares de las rameras preñadas

llamándolos semillas de pimienta en fuerte de marfil!

Di, di, hijo mío, la palabra que demuele el humo cotidiano!"17.

Asimismo, ese hacer con la palabra a más de darle responsabilidad y soledad, le da el poder del Vaticinio.

\section{¡Vengo cada mil!}

iA desposorios y matanzas, llego cantando!

Sólo un instante emerjo de la noche

¡Para mirar mi cuerpo al sol de los maizales y las tumbas!

¿Y muero de la herida que abro incesantemente al avanzar!

¡Oh, Piel oscura, siempre abierta y adherida...!18

Oigo cantar a las pirámides, unas canciones góticas...

Me estoy ahogando en un cacharro ilogico. ${ }^{19}$
Como en Cernuda, esta cognición le hace aceptar el precio de su elección. Se reconoce como hacedor de la palabra. Al hacerlo el sin sentido de la vida, adquiere la auténtica compresión de la humanidad, si se parafrasea a Heidegger, en una parte de $E l$ ser y el tiempo.

La voz poética al aceptar que ese mundo creado tendrá una locación en sí, siente dolor y zozobra: “...ya había resuelto encontrar el asco / y la sabiduría en mí mismo". Ese sentir se plasma en el poema "Espina emplumada". Llega al extremo de su ensimismamiento, que cuando habla se transforma en blasfemo:

\section{"Herencias"20}

Heredamos minas de sal y minas de diamantes.

Documentos para encender batallas en selvas venideras

o sobre esplendentes masas de deyecciones de aves a orillas del Océano.

Heredamos disfraces zoomorfos y máscaras de esgrima.

Heredamos la fórmula para embalsamar cadáveres de obispos,

16 p. 325.

17 "Vaticinios", p. 201.

18 íd., p. 208.

19 "La Vida es vapor", p. 93.

20 íd., p. 323. 
jabalies, voltaires y discóbolos.

Heredamos el revólver de sílex y la mordaza de cuero.

Heredamos hermosos exorcismos contra el óvulo fecundado durante la

Cuaresma.

Heredamos el semen, la estricnina, la avaricia.

Heredamos el furor de salvarnos pisoteando las manos,

del que se agacha a comer lodo por Amor. Heredamos palabras emputecidas hace siglos. Heredamos la manía de aferrar por la cola la bella piel de la Mona verdulera del Paraíso.

Heredamos la mesa.

$Y$ la náusea.

Continúa en "Actos de desesperación" ${ }^{21}$ y concluye con dos versos que sentencian y juegan con la misma esencia -lo divino- del Sumo Constructor:

Porque el futuro depende del perdón que todos los animales juntos en el Hombre otorguen a su viejo creador22.

$\mathrm{Su}$ voz orgullosa muestra su creación, que es la no-Creación (por relación es incompatible con el concepto anterior). Está en sí mismo. Es la manera de oponerse a la acción de Dios desde su propia acción, pues, su construcción no puede librarse del olor humano. ¡Gran Chaco, qué bien huelen tus sepulcros! (...) Yo me acuso de haberte creado, ..." En sí, cada verso de "Cacería del Buho"23. Si se recuerda, la imagen de la ciudad como cementerio -gritado por Cernuda-, el verso citado tiene resonancias de esa imagen; mas para esta voz poética las tumbas como símbolo de las construcciones no conforma un leit motiv.

Este viaje del mundo creado al no-Creado, se inicia en "Origen II", pasa por "El recuerdo es un ácido seguro"24, "Vacío, país salvaje" 25 y
El descubrimiento de ese no-Lugar se da en el poema "En un lugar no identificado"; se da cuenta que es en su interior donde está la no-Creación y se relaciona con el cantar, por ello, se transmuta. 
concluye en "El Ego cuenta a sus mamíferos", en especial, en los versos: "Salgo de las profundas convicciones, de las ideologías/de la ósmosis" 26 ,donde describe ese alejamiento placentero que es la búsqueda del poeta en sí.

El descubrimiento de ese no-Lugar se da en el poema "En un lugar no identificado"; percibe que es en su interior donde está la no-Creación y se relaciona con el cantar, por ello se transmuta. Este es el segundo estadio, que lo llevará al encuentro de su esencia. Es tan importante este lema, que las connotaciones dadas tendrán una evolución en toda la poética de esta voz, por lo cual se ha designado la última parte del texto para este estudio exclusivo.

Es tan sublime y vulgar su relación con su lugar no-Creado que mantiene una cópula constante -una dominación-. La obsesión por "el vaso ceremonial" y todo el léxico alusivo a lo erótico es el vestigio de su constancia. Por ejemplo, en "Funerales de pez insumergible"27: "Baraja hembra con el vello de corcho empapado en sol (...) / Llegaba después de los acuosos partos de sus Madres. (...) / Hidra / Hi$\mathrm{dra} / \mathrm{Hidra} / \mathrm{tu}$ vientre de amianto replegado hacia adentro; ..."28, etc.

La conclusión a la que llega es desesperanzadora. A pesar de su búsqueda, de su no-Creación -Tierra Prometida de Cernuda-, al final, todo será en vano, porque, en un instante la voz poética afirmará: "yo elijo una vez más / la bestia impura que ha de conducirme a la nada [la cópula, la procreación] "29 Ese, el último estadio -de tintes apocalípticos- es al que está condenado. Ahí sucumben todos, es la esencia de la humanidad. $\mathrm{Al}$ final, “...todos tendrán Nada30. No se preserva nada.

Aquel que se ha perdido y está entre tantos $y$ en contra de todos sin ser reconocido,

proviene de un Lugar destruido en Él mismo, a causa de tanto retornar sin haber escapado a la Corriente. (...)

¿Quién, después de uno de nosotros será el mismo o el otro de siempre,

¿Con quién preservar la intemperie pura de la Nada?31 
Lo único poseído es la Nada, por eso, su no-Creación yace En un lugar no identificado.

En este océano de imágenes sin tallar, no hay búsqueda ni acción ${ }^{32}$. Nadie habrá33.

Ni siquiera el poeta, pues su búsqueda termina por mostrarle la verdad: la nada. Esa pesadumbre lo sume y hace de su Creación una noCreación, porque es la refracción en sí mismo, en su interior de lo creado por un Sumo Ser, Otro que no es él. Esta cognición lo sume en una actitud violenta, lo que produce una poesía que grita angustia tanto a nivel sémico como morfo-sintáctico, por su alto número de desvíos. No es raro entonces que hable de destrucción, de podredumbre. Es una voz que se revuelve en sí misma con el desencanto del sin sentido de la vida, es una lucha consigo mismo. Si se recuerda, a la voz cernudiana le preocupa el olvido de Dios, de sus amigos, lo que le lleva a crear su Tierra Prometida, un lugar en las nubes donde sí es posible renacer con lo visible-, nunca se siente un auto-acabamien- to, ni la impotencia que se manifiesta en su par ecuatoriano.

Sin embargo, a pesar de conocer que la búsqueda lleva a la nada, pone en un lema un poder trascendental: cantar y toda su conexión paradigmática tienen, en César, una semiosis autónoma. En primer lugar, se respeta su denotación; mas de manera imperceptible y simultánea al descubrimiento de la vacuidad en el proceso de creación, ésta también sufre transgresión. La evolución sémica y contextual no es cronológica ni lógica, sino, reconocible por la tensión manifiesta.

Cantar en un nivel morfo-asociativo y semántico se relaciona con entonar, canción, canto, que lexicalmente son sinónimos, combinaciones o derivaciones. Mas, existe otra que se extiende a los signos lingüísticos próximos; en un primer estadio, estaría oír y escuchar. Aquí se presenta una ruptura sémica, porque la implicatu$\mathrm{ra}^{34}$ las deslinda y las coloca en dos esferas antagónicas: mientras oír es a lo material; escuchar es a lo etéreo; en un segundo lugar, el abanico paradigmático se abre aún más, para incluir en lo "material", lo no deseado, por ende, a otros signos lingüísticos: 
voz, sonido, armonía. Parecería irónico, escindir estas dos últimas de lo sublime, siendo que culturalmente se concatenan; pero es así, en la lógica de César Dávila: hay una cruel armonía ${ }^{35}$. Sin embargo, hay que aclarar que los desvíos no son formas negativas de desechar significados y sentidos, sino que son puntos de tensión que indican la reflexión de la voz poética, momentos de duda, que le hacen compartir con el lector un meta-poema. Así ocurre, en un fragmento versal, cuando da un epíteto, aparentemente lejano, pero anaforizante, por el carácter acústico-semántico de sus imágenes visuales.

\section{Aquí están los herreros}

Poblando de caballos el sonido ${ }^{36}$.

Lo opuesto va a suceder cuando el cantar sea relacionado con escuchar, porque están dentro de las connotaciones de pureza. A tal punto, que no se destruye su diafanidad, sino que se alude a ella como una mística comunicación $-\mathrm{a}$ veces $f e$ menina- que se libera cuando se transforma de poema en creación poética. No se dejan esperar, entonces, metáforas verbales:

Muros de enredaderas salpicadas de nidos $y$ de orugas,

Cuelgan de los acantilados y cantan sobre los féretros de los delfines ${ }^{37}$.

Aún no ha sido claveteado el pajar

Con aquellos pies de grillo

En donde cantaba la pequeña tabaquera de Schubert ${ }^{38}$.

En Canción a la bella distante-dedicado a Laura ¿una mujer en realidad, o a su etimología: laurel (derrota/ triunfo)?-, se nota claramente, porque cada frase trasluce no un ser corpóreo, sino aquel negado en la primera línea versal: juego de atención para notar la doble negación.

No era mi poesía. Mis poemas no eran. Eras tú solamente [la Poesía: Arte] , perfecta como un surco Abierto por palomas ${ }^{39}$.

Otra prueba del acercamiento a este lema es la incidencia de los títulos de sus poemas: "Canción para una muchacha de ojos verdes", "Canción a Teresita", "Canción espiritual”, 
"pequeña Canción", "Canción del tiempo esplendoroso", "Canción al templo antiguo", "Canción a la bella distante", "Canción para verte en este día", "Canción a la cadena del blanco amor", "Una canción para mi nuevo nacimiento", "Canción a Rita", "Canción frente a un colegio", "Canción para la aureola de una joven llamada María", "Canción y Homenaje", "Canción elemental para Isabelita", "Canción a Isabelita", "Canto al hombre a su ignorado ser", ... "Poema, Palabra Perdida". La mayoría se relaciona con esta actividad.

Hay aun un proceso, pues cuando es perfección, es poesía: una unión liberadora, que no necesita reflexión; así lo asevera la voz poética al usar los deícticos este, el, mi, esta. .../ este canto, mi canto apasionado. / Esta canción es tuya, Capitana... ${ }^{40}$ Su uso obedece a una consolidación de un encuentro con la actividad poética y su propia voz en el arte. Yo no quiero cantar tu vida inmensa / reflejada en mortal fotografía ${ }^{41}$. La presencia de la nada se escucha en uno de sus textos, donde a partir de una arrebatada dubitación, el reflexionar sobre su mundo le muestra la pérdida de lo anhelado. Entonces, se hunde en la desesperación, en la palabra perdida; por ello antropomorfa el poema y la creación con imágenes sugerentes.

La creación se apoya en un solo punto antes de trepar

En torno de la Vara.

Sin ese punto, el virgo deviene agua.

Como el olvido de sí mismo,

El centro está en todas partes.

$$
\text { (...) }
$$

Internándose más

El poema puede estallar al otro lado de su rostro ${ }^{42}$.

Es tal el respeto de la voz poética por el cantar y su actividad, que en aquellos poemas titulados con ella, existe una carencia casi completa del mismo; por lo tanto, se asevera el deseo de no-transgresión lingüística. Ellos aparecen con su denotación en el resto de poemas. Es un indicio de lo que es esta acción. También, hay que resaltar un apoyo fonológico solemne, ya que muchas de las combinaciones morfológicas encuentran un ritmo acentuado en las vocales de perceptibilidad de segundo y tercer $o-e-a$. El efecto es el ritmo de canto, pero no de cualquiera, sino uno ele- 
vado: uno lírico, que en este caso pertenece a las notas graves - porque en el coro, las vocales anteriores son de las voces masculinas bajas-, que combinado, con la sensibilidad de la creación, parecería un acto sexual purificador o de unión celestial a través del placer. Representa la coexistencia propia de lo estético.

\section{La posible dubitación se presenta de una manera indirecta, pues se utiliza un segundo nivel narrativo.}

Entre tus panteras de inextinguible piel de hembra.

Volando entre tus ámbitos de zafiro y de prismas.

Entre los bosques y su miel humeante. Entre el coro granate de la madre libre $Y$ el carmín inguinal de la resina ${ }^{43}$.

Se debe considerar que la reflexión llega a un extremo máximo, cuando se cuestiona el mismo signo- huella. Se inicia haciendo evidente la bipartición del mundo creado; éste está constituido por cadenas y cantos ${ }^{44}$; asimismo, se considera la existencia humana, la del poeta, iAmauta valeroso, toda verdadera canción es un naufragio/;Aquí, no cantará nunca el pajarillo matinal! 45

La posible dubitación se presenta de una manera indirecta, pues se utiliza un segundo nivel narrativo. La voz inserta increpa sobre la labor del propio escritor, ya que su poder es sumo: la palabra abre mundos.

“ Ah del poeta que hiere con su citara almejilla del pobre

y canta los lunares de las rameras preñadas

llamándolos semillas de pimienta en fuerte de marfil!

Di, di, hijo mío, la palabra que demuele el humo cotidiano!"46

"Rumores de mundanas hipotecas se enroscan a tu canto" 47 .

¡Cántico dará la piedra umbral!

¡Oh cuerpo puro; hombre infinito en cuya vestimenta milenaria

las barrancas silvestres entonan la alabanza de los surcos! ${ }^{48}$

43 “Canción del Tiempo", p. 147.

44 “Esquela al gorrión doméstico", p. 158.

45 "Catedral Salvaje", p. 182.

46 "Vaticinios", p. 201.

47 íd.p. 203.

48 íd., p. 205. 
Existe un momento cuando la voz poética hace un parangón entre el Creador y el creador de mundos con palabras y cantos; lo que exhorta no a una herejía, sino a una reflexión sobre la acción, el hacer.

Luego de este ensalzar la acción de cantar, que parecería un baño de purificación, se vuelve a la comprensión de que la nada es lo único que queda. La muerte en esta cosmovisión pasa a ser una ayudante de esa angustiosa resolución: la destrucción de lo creado en sí mismo. Por ello, esta decisión es lo que hace de César una voz muy diferente a la de Cernuda. En cuanto a la muerte, ambas tienen una percepción muy diferente, para la una es un momento más; mientras que para la otra es un momento de tensión, porque cambia de significado al ser concebida como nacimiento. En sí, lo desesperanzador adquiere valor sumo en el poeta ecuatoriano, lo que queda en proceso en el poeta sevillano.

Como se ha demostrado en el transcurso de la presente lectura, la utilización de los lemas no son arbitrarios en la poesía, ya que, detonan una intención velada, la reflexión sobre la lengua misma: eso es la CREACIÓN. El valor de cada fone- ma, morfema se adhiere a una gramática determinada, la que el autor construye en el transcurso de su obra. El conflicto se da cuando las gramáticas de cada lector salen a flote y catalogan los signos, dándoles una semiosis distinta, sin escuchar las resonancias textuales presentadas. La poesía exige que el/la lector/a se transforme en poeta, entable una conversación única e irrepetible, constructora de voces y máscaras con la palabra.

La voz poética lucha por comunicarse, pero comprende el desgaste de los signos, por ello, crea otros mundos, donde sus valores son distintos: es una desmitificación. La desviación es producto de ese deseo; es un juego provocador de tensión en los significados; al analizar la lógica queda al descubierto lo oculto.

Gran labor asignada a quien lee, pues se convierte en investigador y poeta, dejando su antiguo sitial de espectador pasivo, que ve un mundo sin ser parte de él. La estética cernudiana y daviliana rompe con este criterio y prodiga al lector-poeta la labor de descubrir y co-crear el mundo. Es una nueva mirada de lo existente con las herramientas familiares; lo extrapolar, la técnica requerida, signada en los mismos poemas. 


\title{
Rosario A'Imea Suárez
}

\section{Bibliografía}

\author{
ANTELO, Raúl \\ 2006 Poesía hermética y surrealismo, http://www.geocities.com/a fonte 2000/ante- \\ lo4.htm, consultado el 04-05-06. \\ ÁRIAS MICHELENA, Rafael, et al. \\ 1977 Número monográfico sobre César Dávila Andrade de la Revista de la \\ Universidad Católica del Ecuador n. 15, Quito, PUCE, enero de. \\ CERNUDA, Luis \\ 2003 Poesía del exilio, España, Fondo de Cultura Económica. \\ DÁVILA ANDRADE, César \\ 1984 "En un lugar no identificado", Obras Completas: Poesía, Cuenca, Universidad \\ Católica y BCE. \\ DÁVILA ANDRADE, César \\ 1984 Obras Completas: Poesía, Cuenca, Universidad Católica y BCE. \\ DE ZULETA, Emilia \\ 1981 "La poesía de Luis Cernuda", Cinco poetas españoles, Segunda Edición, Madrid, \\ Gredos. \\ ESPINASA, José María \\ 2002 "Mejor la destrucción, el fuego", Cuadernos hispanoamericanos, 625-626, Sala- \\ manca, julio-agosto. \\ JÁCOME, Gustavo Alfredo \\ 1977 “César Dávila Andrade: ¿Luzbel o Lucifer?”, Estudios estilísticos, Quito, Editorial \\ Universitaria. \\ POZUELO YVANCOS \\ s/f Teoría del lenguaje literario, Madrid, Cátedra. \\ PRIETO DE PAULA, Ángel \\ 2002 "Una desolación sin adjetivos", Cuadernos hispanoamericanos, 625-626, Sala- \\ manca, julio-agosto. \\ QUIRARTE, Vicente \\ 1985 La poética del hombre dividido en la obra de Luis Cernuda, México, Universidad \\ Nacional Autónoma de México. \\ SOTELO VÁZQUEZ, Adolfo \\ 2002 Luis Cernuda ante la crítica y la tradición literarias", Cuadernos hispanoamerica- \\ nos, 625-626, Salamanca, julio-agosto.
}

